\title{
PEMANFAATAN SISTEM INFORMASI GEOGRAFIS UNTUK ARAHAN PENGGUNAAN LAHAN DI DAS PERCUT, SUMATERA UTARA
}

\author{
Riki Rahmad, Adelina Sormin \\ Jurusan Pendidikan Geografi, Fakultas IImu Sosial, Universitas Negeri Medan \\ JI. Willem Iskandar Psr V Medan, 20221, Indonesia \\ Email: rikirahmad@unimed.ac.id
}

\begin{abstract}
Abstrak
Tujuan penelitian ini adalah untuk mengetahui arahan penggunaan lahan di Daerah Aliran Sungai Percut dengan memanfaatkan Sistem Informasi Geografis. Populasi dalam penelitian ini adalah seluruh daerah Sub DAS Percut. Teknik pengambilan sampel yang digunakan adalah total sampling, yaitu populasi sekaligus dijadikan sampel. Teknik analisis data yang digunakan dalam penelitian ini adalah teknik analisis kualitatif dengan pengharkatan (scoring) pada parameter penelitian berupa overlay/ tumpang susun peta. Overlay peta merupakan teknik analisis dalam SIG untuk mengetahui dan melakukan analisis keruangan yang dilakukan dengan cara tumpang susun antara beberapa peta dengan berbeda, yang menggunakan perangkat lunak ArcGIS. Hasil penelitian menunjukkan bahwa arahan penggunaan lahan di DAS Percut terdiri dari 3 kawasan, yaitu Kawasan Lindung dengan luas 4.258,19 Ha atau 9,9\% dari keseluruhan daerah penelitian. Kawasan penyangga yaitu dengan luas 9.250 Ha atau (21,7\%) dan Kawasan Budidaya tanaman semusim dan permukiman yaitu dengan luas 29.250 Ha atau $68,4 \%$.
\end{abstract}

Kata kunci: DAS Percut, SIG, Arahan Penggunaan Lahan

\section{PENDAHULUAN}

Daerah Aliran Sungai (DAS) adalah daerah yang dibatasi oleh punggung bukit dimana air hujan yang jatuh akan mengalir ke dalamnya melalui alur-alur menuju anakanak sungai kemudian terkonsentrasi menuju sungai utama dan berakhir di laut. Pada DAS inilah semua aktivitas manusia di darat berlangsung, dan di daerah ini juga rawan akan terjadinya banjir dan tanah longsor. Pemetaan daerah rawan bencana tanah longsor ini dapat dilakukan dengan menggunakan berbagai aplikasi atau software pemetaan pada SIC, seperti dengan menggunakan ArcGIS (Rahmad, Suib, \& Nurman, 2018). Selanjutnya Damanik dan Restu (2012) menyebutkan bahwa SIC juga dapat diterapkan untuk menganalisis tingkat risiko banjir.

Penggunaan lahan merupakan salah satu faktor yang berpengaruh terhadap fungsi tata air suatu DAS. Penggunaan lahan yang tepat dapat memberikan keuntungan bagi daerah di sekitarnya tetapi penggunaan lahan yang tidak tepat dapat memberikan kerugian bagi daerah di sekitarnya.
Perubahan penggunaan lahan di suatu wilayah dapat mempengaruhi fungsi tata air (hidro-orologi). Hal ini sesuai dengan pendapat Arsyad (2009), yang menyatakan bahwa setiap perlakuan yang diberikan pada sebidang tanah dapat mempengaruhi tata air di tempat tersebut dan tempattempat di hilirnya.

Terjadinya bencana alam yang sering terjadi di beberapa daerah selama ini mengindikasikan telah terjadinya kerusakan lingkungan, terutama penurunan dari daya dukung daerah aliran sungai (DAS). Penurunan luas vegetasi merupakan masalah serius pada ekosistem DAS (Rahmad, Nurman, \& Wirda, 2017). Kurangnya daya dukung DAS dapat dilihat dari semakin banyaknya lahan yang seharusnya dimanfaatkan sesuai dengan arahan penggunaan lahan tidak dimanfaatkan sebagaimana mestinya. Sebagai wilayah, DAS juga dipandang sebagai ekosistem dari daur air, sehingga DAS didefinisikan sebagai suatu wilayah daratan yang merupakan satu kesatuan dengan sungai dan anak-anak sungainya, 
yang berfungsi menampung, menyimpan, dan mengalirkan air yang berasal dari curah hujan ke danau atau ke laut secara alami. Batas di darat merupakan pemisah topografi dan batas di laut sampai dengan daerah perairan yang masih terpengaruh aktivitas daratan (Undang-undang RI No. 7 Tahun 2004).

Daerah aliran Sungai adalah kawasan yang mengalirkan air yang jatuh diatasnya ke dalam suatu sistem aliran sungai yang mengalir dari hulu menuju muara atau ke tempat-tempat pengukur arus (FAO 1962, diacu dalam Sheng 1968). Pawitan (2004) menyatakan bahwa Daerah Aliran Sungai merupakan satu kesatuan wilayah berupa sistem lahan dengan tutupan vegetasinya, dibatasi oleh batas-batas topografi alami (seperti punggung bukit) yang menerima curah hujan sebagai masukan, mengumpulkan dan menyimpan air, sedimen dan unsur hara lainnya serta mengalirkannya melalui anak-anak sungai untuk akhirnya keluar melalui satu sungai utama ke laut atau danau.

Menurut Arsyad (2009) penggunaan lahan dapat dikelompokan ke dalam penggunaan lahan pertanian dan penggunaan lahan non pertanian. Penggunaan lahan pertanian meliputi hutan, sawah, ladang, perkebunan, dan lainnya. Penggunaan lahan non pertanian seperti pemukiman, industri, dan perkantoran.

Istilah penggunaan lahan berkaitan dengan aktivitas manusia atau fungsi ekonomi yang berhubungan dengan sebidang lahan tertentu (Asdak, 2004). Menurut Arsyad (2009), setiap perlakuan yang diberikan pada sebidang tanah akanmempengaruhi tata air di tempat itu dan tempat - tempat di hilirnya.

Menurut (Sinukaban, 2001), pemanfaatan Sumber Daya Alam Daerah Aliran Sungai (DAS) yang tidak memperhatikan kemampuan dan kelestariannya akan menyebabkan terjadinya kerusakan pada lahan dan gangguan tata air. Arsyad (2009) yang mengemukakan bahwa lahan yang kritis secara hidrologi ditandai oleh besarnya angka perbandingan antara debit maksimum (musim hujan) dengan debit minimum (musim kemarau) serta kandungan lumpur yang berlebihan.

Penggunaan lahan secara umum dipengaruhi oleh dua faktor utama yaitu faktor alami seperti iklim, topografi, tanah atau bencana alam dan faktor manusia berupa aktivitas manusia pada sebidang lahan. Faktor manusia dirasakan berpengaruh lebih dominan dibandingkan dengan faktor alam karena sebagian besar perubahan penggunaan lahan disebabkan oleh aktivitas manusia dalam memenuhi kebutuhan pada sebidang lahan yang spesifik (Nursa'ban, 2006)

Adnyana \& As-syakur (2012) mengemukakan bahwa analisis untuk penetapan arahan pemanfaatan lahan dilakukan dengan menggunakan perangkat SIC dengan proses overlay. Putra dan Mardiatno (2012) mengemukakan bahwa dengan menggunakan proses overlay dari peta tanah, peta lereng dan peta geomorfologi sehingga dapat dihasilkan bahwa keadaan topografi DAS. Pahlawan dan Worosuprojo (2013) mengemukakan bahwa berdasarkan hasil overlay dari bentuk lahan, kelerengan, penggunaan lahan dan tanah didapatkan arahan penggunaan lahan SubDAS Percut.

Arahan penggunaan lahan merupakan upaya penataan suatu wilayah Arahan menjadi suatu kawasan-kawasan dengan fungsi berbeda-beda sesuai dengan kemampuannya (Listyawati, 2010). Fitrianti, dkk (2013) menjelaskan tentang arahan pemanfaatan/ penggunaan lahan merupakan kajian potensi lahan untuk peruntukan suatu kegiatan dalam suatu kawasan tertentu berdasarkan fungsi utamanya. Dalam hal ini tujuan dari arahan fungsi pemanfaatan lahan adalah untuk mencapai keseimbangan antara kemampuan lahan dengan jenis pemanfaatan dan teknologi yang digunakan sebagai upaya untuk melindungi fungsi dan sumber daya alam di suatu wilayah. Artinya apabila Pemanfaatan lahan di masingmasing kawasan tidak sesuai dengan fungsi utamanya maka perlu dilakukan tindakan arahan fungsi pemanfaatan lahan dengan menerapkan tindakan rehabilitasi lahan dan konservasi tanahsecara vegetatif dan mekanik yang berfungsi untuk mengembalikan dan menjaga fungsi utama kawasannya. Berbagai keterangan tentang kemungkinan pemanfaatan dan pembatas pembatas dari faktor lingkungan yang bersifat permanen maupun sementara sangat penting diperhatikan dalam membicarakan perencanaan perubahan pola penggunaan lahan.

Bencana dan kerusakan Lingkungan terjadi karena adanya pemanfaatan lahan yang tidak mempertimbangkan 
keseimbangan ekosistem. Oleh karena itu, harus dilakukan penataan ruang yang memperhatikan keseimbangan ekosistem. Penetapan fungsi kawasan lindung, fungsi kawasan penyangga dan fungsi kawasan budidaya merupakan salah satu bentuk upaya untuk menjaga kelestarian lingkungan dan keseimbangan ekosistem alam. Dengan memanfaatkan aplikasi Sistem Informasi Geografis dapat digunakan untuk membantu dalam menentukan arahan fungsi pemanfaatan lahan di DAS dan mengetahui kesesuaian penggunaan lahan sesuai dengan arahan fungsi pemanfaatan lahan.

Sungai Percut merupakan salah satu dari beberapa sungai yang ada di kota Medan yang termasuk dalam kategori kritis. Daerah aliran sungai ini merupakan daerah rawan banjir pada saat musim penghujan datang, banyak hal yang menyebabkan daerah ini rawan banjir salah satunya adalah perubahan tata guna lahan di sekitar aliran sungai Percut. Untuk mengatasi hal tersebut dibutuhkan langkah-langkah penanggulangan yang tepat, antara lain dengan adanya suatu bangunan pengendali banjir.

Daerah pengaliran (catchment area) Sungai Percut berbentuk bulu burung yang meliputi beberapa bagian dari kecamatan Percut Sei Tuan, Batang Kuis, Pantai Labu, Sibolangit, Tanjung Morawa, Patumbak, Biru-biru, STM Hulu dan STM Hilir. Tidak seluruh luasan dari masing-masing kecamatan tersebut masuk ke dalam daerah pengaliran Sungai Percut, akan tetapi hanya beberapa bagian saja.

\section{METODE PENELITIAN}

Penelitian dilaksanakan pada arahan Penggunaan Lahan di Daerah Sub DAS Percut. Populasi dalam penelitian ini adalah seluruh daerah DAS Percut. Teknik pengambilan sampel yang digunakan adalah total sampling, yaitu populasi sekaligus dijadikan sampel.

Dalam penelitian ini teknik pengumpulan data yang digunakan yaitu:

1. Teknik Dokumentasi

Teknik dokum dalam penelitian ini digunakan untuk data data sekunder mengenai keadaan dan pemanfaatan lahan, peta lokasi daerah penelitia, peta jenis tanah, peta curah hujan, dan data data yang dibutuhkan dalam penelitian ini, baik dari Badan Perencana Pembangunan Daerah, dan instansi terkait lainnya.
2. Interpretasi Citra

Interpretasi citra peta dengan peta data SRTM dan data titik stasiun curah hujan. Citra SRTM diperoleh dari sumber internet (hup: //usgs.gov). Dari citra yang dihasilkan maka dilakukan generalisasi dengan menggunakan software Global Mapper untuk mendapakatkan data kontur, dilanjutkan dengan peta menggunakan software ArcGIS untuk mengubah data kontur menjadi kemiringan lereng.

Teknik analisis data yang digunakan dalam penelitian ini adalah teknik analisis kualitatif dengan pengharkatan (scoring) pada parameter penelitian yang akan di overlay/tumpang susun.

\section{Skoring}

Skoring dilakukan untuk memberikan bobot dari poligon-poligon wilayah yang memiliki kesamaan karakteristik pada peta tematik seperti yang telah ditetapkan dalam SK Menteri Pertanian Nomor 837Kpt/ um/ll/ 1980 dan Keputusan Presiden Nomor 32 Tahun 1990. Sedangkan untuk data curah hujan berpedoman pada ketentuan yang ditetapkan oleh BBSDLP (2009).

\section{Interpretasi Peta}

Dalam penelitian ini ada dua jenis interpretasi peta yaitu di foto dan non-foto. Interpretasi foto digunakan untuk menghasilkan peta dalam bentuk vektor dari data dalam format foto (JPEC, dll). Sedangkan Interpretasi non digital dalam format digital elevation model (DEM). Interpretasi foto digunakan untuk menhasilkan Peta jenis tanah dan peta penggunaan lahan. Sedangkan interpretasi non-foto digunakan untuk menghasilkan peta kemiringan lereng dan peta intensitas curah hujan.

\section{Overlay Peta}

Overlay peta merupakan teknik analisis dalam SIC untuk mengetahui dan melakukan analisis keruangan yang dilakukan dengan cara tumpang tindih antara beberapa peta dengan berbeda, yang menggunakan perangkat lunak ArcGls. Melalui program SIC dengan cara overlay peta peta tematik, maka akan diperoleh satuan lahan menurut klasifikasi dan nilainya. Penetapan arahan penggunaan lahan dilakukan dengan menjumlahkan skor dari tiga faktor yang menilai pada setiap satuan lahan. Beberapa skor terebut akan mencerminkan kemampuan lahan untuk masing-masing satuan lahan. Berdasarkan 
total skor, akan diperoleh arahan penggunaan lahan dari masing-masing satuan lahan. Teknik ini sangat penting untuk digunakan sebagai alat untuk mempermudah analisis keruangan. Adapun data yang digunakan berupa data atribut dan data spasial dari peta administrasi. Kelerengan, curah Hujan, Jenis tanah dan penggunaan Lahan DAS Percut dengan Sistem Proyeksi UTM zona 47 N, Datum WGS 1984.

\section{Langkah Kerja}

a. Tutupan Lahan Berbasis Tata Ruang

Analisis tutupan lahan berbasis tata ruang dilakukan secara kualitatif dari interpretasi peta penggunaan lahan Existing DAS Percut, dan dengan menggunakan analisis data spasial dan data atribut pada perangkat lunak ArcGIS 10.1 dapat berupa bentuk-bentuk penggunaan lahan dan luasnya secara terperinci.

b. Skoring Parameter Arahan Penggunaan Lahan

Dalam menetapkaan arahan penggunaan lahan dilakukan dengan pemberian nilai (skoring) dan pengharkatan pada parameter penelitian yang telah diklasifikasikan yaitu Kemiringan Lereng, jenis tanah dan intensitas curah hujan. Sistem skoring yang digunakan sesuai dengan SK Mentan Nomor 837/Kpts/Um/ $11 / 1980$ dan SK Mentan Nomor $683 / \mathrm{Kpts} / \mathrm{Um} / 8 / 1981$ yang ditampilkan pada tabel 1,2 dan 3 sebagai berikut:

Tabel 1. Skor Lereng

\begin{tabular}{cccc}
\hline $\begin{array}{l}\text { Kelas } \\
\text { Lereng }\end{array}$ & $\begin{array}{l}\text { Kisaran Lereng } \\
(\%)\end{array}$ & Keterangan & $\begin{array}{l}\text { Hasil Nilai } \\
\text { Kelas } \times \text { Bobot }\end{array}$ \\
\hline 1 & $0-8$ & Datar & 20 \\
\hline 2 & $8-15$ & Landai & 40 \\
\hline 3 & $15-25$ & Agak Curam & 60 \\
\hline 4 & $25-45$ & Curam & 80 \\
\hline 5 & $>45$ & Sangat Curam & 100 \\
\hline \multicolumn{5}{r}{ Sumber: Kepmentan No: $837 /$ Kpts/Um/11/1980 }
\end{tabular}

Tabel 2. Skor Jenis Tanah

\begin{tabular}{clcc}
\hline $\begin{array}{l}\text { Kelas } \\
\text { Tanah }\end{array}$ & Kelompok Jenis Tanah & $\begin{array}{l}\text { Kepekaan } \\
\text { Terhadap Erosi }\end{array}$ & $\begin{array}{c}\text { Hasil Nilai } \\
\text { Kelas x Bobot }\end{array}$ \\
\hline 1 & $\begin{array}{l}\text { Aluvial, Tanah, Glei, } \\
\text { Planossol, Hidromorf } \\
\text { Kelabu, Literite Air Tanah }\end{array}$ & Tidak Peka & 15 \\
\hline 2 & Latosol & Agak Peka & 30 \\
\hline 3 & $\begin{array}{l}\text { Brown Forest Soil, Non } \\
\text { Calcic }\end{array}$ & Kurang Peka & 45 \\
\hline 4 & $\begin{array}{l}\text { Andosol, Laterictic } \\
\text { Gromusol, Podsolik }\end{array}$ & Peka & 60 \\
\hline 5 & $\begin{array}{l}\text { Regosol, Litosol Organosol, } \\
\text { Renzine }\end{array}$ & Sangat Peka & 75 \\
\hline
\end{tabular}

Sumber: BBSDLP (2009)

Tabel 3 Skor Curah Hujan

\begin{tabular}{ccccc}
\hline No & Kelas & Hujan $(\mathrm{mm} / \mathrm{hr})$ & Klasifikasi & Skor \\
1 & I & Kecil dari 1000 & Sangat Kering & 10 \\
2 & II & $1001-2000$ & Kering & 20 \\
3 & III & $2001-3000$ & Sedang & 30 \\
4 & IV & $3001-4000$ & Basah & 40 \\
5 & V & Besar dari 4000 & Sangat Basah & 50 \\
\hline
\end{tabular}

Sumber: BBSDLP (2009)

Tabel 4. Fungsi Kawasan

\begin{tabular}{ccll}
\hline No & Kelas & \multicolumn{1}{c}{ Fungsi Kawasan } & Skor Total \\
\hline 1 & I & Lindung & Lebih besar dari 175 \\
\hline 2 & II & Penyangga & $125-174$ \\
\hline 3 & III & $\begin{array}{l}\text { Budidaya ( Tanaman Tahunan, } \\
\text { Musiman dan Permukiman ) }\end{array}$ & Kecil Dari 124 \\
\hline
\end{tabular}

Sumber: BBSDLP (2009) 


\section{HASIL \& PEMBAHASAN}

\section{Letak dan Luas}

DAS PERCUT merupakan DAS yang terdapat di daerah beberapa kecamatan, luas DAS Percut yaitu 42.758,19 $\mathrm{Ha}$. Daerah Hulu DAS Percut yaitu terletak di Kecamatan Biru-Biru, Kecamatan Tiga Panah, dan Kecamatan Sibolangit, sedangkan daerah hilir DAS Percut terletak di Medan Labuhan. Secara administrasi DAS Percut berbatasan dengan :

> Sebelah Utara berbatasan dengan Sub Das Deli
> Sebelah Barat berbatasan dengan Sub Das Bekala

$>$ Sebelah Selatan berbatasan dengan Sub Das Simai Mai dan Sub Das Petani

$>$ Sebelah Timur berbatasan dengan Das Belumai dan Das Batang Kuis.

Berdasarkan peta tata guna lahan yang ada, DAS Percut dapat dikelompokkan ke dalam beberapa penggunaan lahan yang luas masingmasing lahan adalah sebagai berikut.

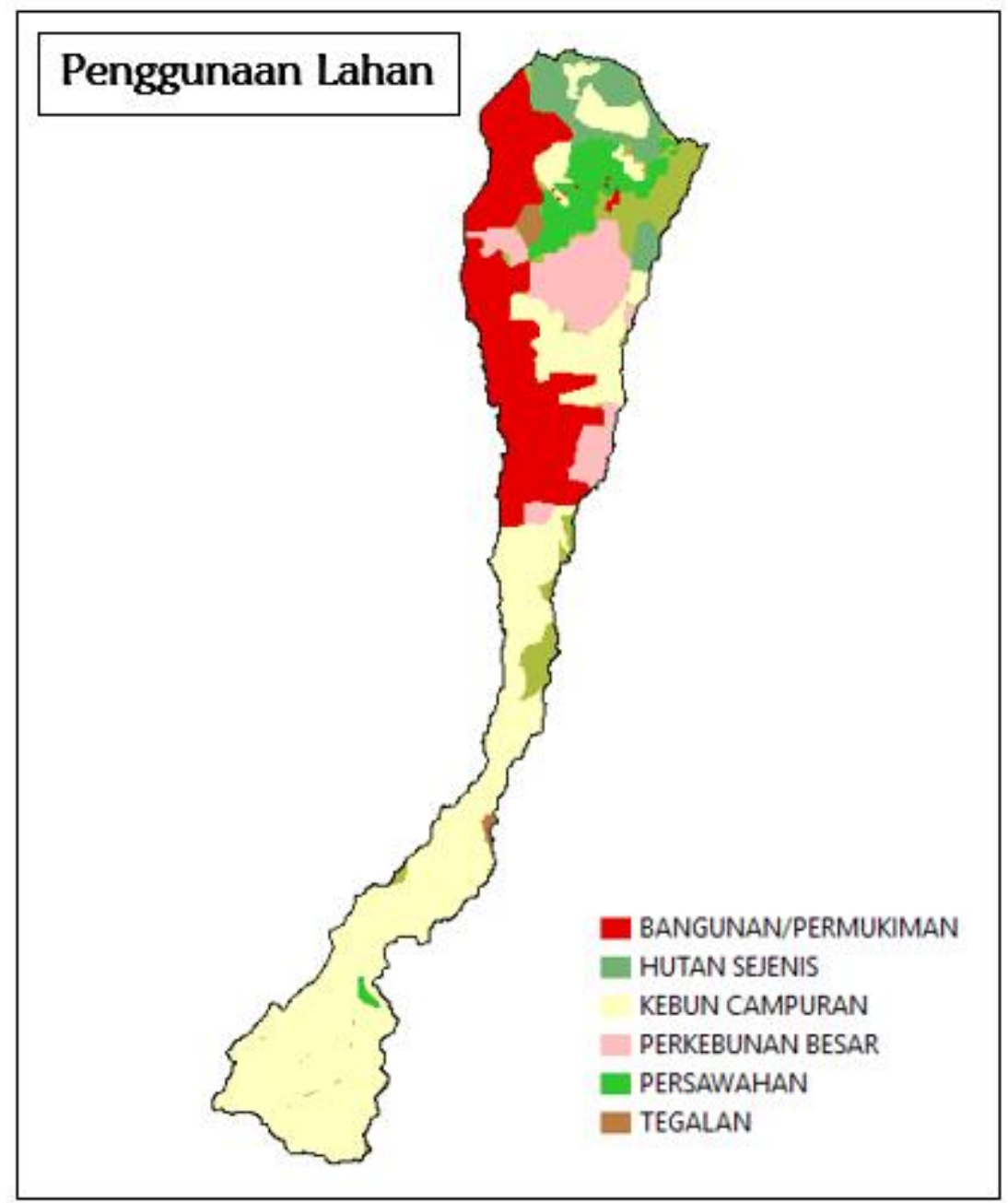

Gambar 1. Penggunaan Lahan DAS Percut

Penggunaan lahan di DAS Percut yaitu Kebun Campuran, Bangunan, Permukiman, Hutan Sejenis, Perkebunan Besar, Persawahan dan Tegalan. Kawasan Das Percut yairu terdapat di Kota Medan, Kabupaten Deli Serdang dan Kabupaten Karo. Daerah Kecamatan yang termasuk kawasan DAS Percut yaitu:

1. Kecamatan Medan Labuhan

2. Kecamatan Medan Belawan

3. Kecamatan Medan Timur

4. Kecamatan Medan Denai

5. Kecamatan Medan Perjuangan

6. Kecamatan Medan Amplas 
7. Kecamatan Medan Area

8. Kecamatan Medan Kota

9. Kecamatan Medan Tembung

10. Kecamatan Percut Sei Tuan

11. Kecamatan Tanjung Morawa

12. Kecamatan Sinembah Tanjung Hilir

13. Kecamatan Sinembah Tanjung Huli

14. Kecamatan Patumbak

15. Kecamatan Biru Biru

16. Kecamatan Tiga Panah

17. Kecamatan Sibolangit

18. Kecamatan Barus Jahe

\section{Pemetaan Arahan Penggunaan Lahan}

Penentuan arahan penggunaan lahan penting dilakukan sebagai langkah awal untuk mengetahui lokasi yang sesuai dalam pembangunan pembangunan kedepan. Selanjutnya dari arahan penggunaan lahan yang tersusun akan didetailkan penggunaannya melalui prasyarat-prasyarat tertentu. Pemanfaatan ruang yang sesuai dengan arahan pengunaannya sangat menentukan kelanjutan pembangunan yang direncanakan.

Penetapan arahan penggunaan lahan diperlukan data-data spasial, yaitu kemiringan lereng, jenis tanah, dan curah hujan. Sedangkan untuk evaluasi kesesuaian antara penggunaan lahan dengan arahan penggunaan lahannya dibutuhkan data penggunaan lahan eksisting di lapangan.

\section{Jenis Tanah}

Jenis tanah memiliki sifat-sifat yang mempengaruhi kepekaan tanah lerhadap erosi yaitu tekstur tanah, bentuk dan kemantapan struktur tanah, permeabilitas tanah dan kandungan bahan organik tanah. Jenis tanah regozol, Lilosol, organosol dan renzina adalah beberapa jenis uanah yang paling peka terhadap erosi. Semakin peka suatu jenis tanah maka akan semakin tinggi harganya, lebih jelas dapat dilihat pada Tabel 6 berikut.

Tabel 6. Luas Jenis Tanah di DAS Percut

\begin{tabular}{cccccc}
\hline No & Jenis tanah & Kelas & Skor & Luas (Ha) & $\begin{array}{c}\text { Presentase } \\
\%)\end{array}$ \\
\hline 1 & Alluvial & Tidak peka & 15 & $11.203,96$ & $26,20 \%$ \\
\hline 2 & Brown Forist Soil & Kurang peka & 45 & $3.730,52$ & $8,72 \%$ \\
\hline 3 & Andosol & Peka & 60 & $15.641,20$ & $36,58 \%$ \\
\hline 4 & Litosol & Sangat Peka & 75 & $11.659,34$ & $28,5 \%$ \\
\hline & Total & & & $42.758,19$ & $100 \%$ \\
\hline
\end{tabular}

Sumber: Analisis Data Spasial, 2017

Berdasarkan Tabel Jenis Tanah dominan adalah jenis yang paling dominan adalah jenis tanah Andosol dengfan tingkat kerentanan peka terhadap erosi dan skor 45 memiliki luas mencapai $15.641,20 \mathrm{Ha}$ atau $36,58 \%$ dari luas total wilayah penelitian. Jenis tanah ini tersebar di beberapa kecamatan precut sei tuan, Medan Tembung, Medan Perjuangan, Medan Timur, Medan deli, Medan Amplas, Patumbak, tanjung Morawa, Kecamatan Biru Biru.

Jenis tanah Aluvial dengan tingkat atas Tidak Peka terhadap erosi dan skor 15 memiliki luas mencapai $11.203,96 \mathrm{Ha}$ atau $26,20 \%$ dari luas total wilayah penelitian. Jenis tanah ini tersebar di beberapa Kecamatan Medan Labuhan, Belawan, Patumbak, Sinembah Tanjung Muda Hilir, Biru Biru.

Jenis tanah Brown Forist Soil dengan tingkat Kurang Peka terhadap erosi dan skor 45 memiliki luas sekitar 3.730,52 Ha atau 8,72 \% dari luas. Jenis tanah ini tersebar di beberapa Kecamatan Labuhan, Belawan, Deli, Medan
Area, Medan Kota, Patumbak, Sinembah Tanjung Muda Hilir.

Jenis Tanah Latosol dengan tingkat sangat pekaterhadap erosi dengan skor 75 memiliki luas sekitar $11.659,34 \mathrm{Ha}$ atau $28,5 \%$ luas keseluruhan daerah penelitian. Jenis tanah latosol menyebar di beberapa kecamatanBiru Biru, Sibolangit, Tiga Panah, dan Barus Jahe.

\section{Kemiringan Lereng}

Kemiringan lereng dan panjang lereng berpengaruh terhadap aliran permukaan dan erosi. Selain memperbesar jumlah aliran permukaan, semakin curam lereng juga memperbesar kecepatan aliran permukaan yang dengan demikian memperbesar energi angkut aliran permukaan. Semakin curam lereng pada suatu kawasan, maka kawasan tersebut tidak boleh dijadikan sebagai kawasan budidaya. Data kemiringan lereng pada Tabel 7. berikut. 
Tabel 7. Lemiringan Lereng DAS Percut

\begin{tabular}{cccccc}
\hline No & $\begin{array}{c}\text { Kemiringan Lereng } \\
(\%)\end{array}$ & Klasifikasi & Skor & Luas (Ha) & $\begin{array}{c}\text { Presentase } \\
(\%)\end{array}$ \\
\hline 1 & $0,00-8,00$ & Datar & 20 & $20.209,35$ & $66,8 \%$ \\
\hline 2 & $8,01-15,00$ & Landai & 40 & 2727,80 & $9 \%$ \\
\hline 3 & $15,01-25,00$ & Agak Curam & 60 & 5757,19 & $17,9 \%$ \\
\hline 4 & $25,01-45,00$ & Curam & 80 & 1557,12 & $6,3 \%$ \\
\hline \multicolumn{7}{c}{} \\
\hline \multicolumn{7}{c}{ Sumber: pengolahan data dengan Citra Aster GDEM, 2017 }
\end{tabular}

Dari hasil analisis Peta Kemiringan Lereng maka didapat daerah dengan kelerengan 0-8 (Datar) dengan skor 20 ada di seluruh wilayah daerah yaitu Kecamatan Patumbak, Tanjung Morawa, Kecamatan Sinembah Tanjung Hilir, Medan Labuhan, Labuhan Deli, Kecamatan Percut Sei Tuan, Kecamatan Medan Denai, Kecamatan Medan Timur, Kecamatan Medan Amplas dan Belawan.

Lahan dengan kemiringan lereng 8 -15 \% Landai dengan skor 40 ada juga di seluruh daerah yaitu Kecamatan Sinembah Tg Muda Hilir, Kecamatan Biru Biru. Lahan dengan kemiringan lereng 15-25 Agak Curam dengan skor 60 ada juga di seluruh daerah penelitian yaitu Kecamatan Kecamatan Sibolangit, Kecamatan Biru Biru,Kecamatan Tiga Panah, Kecamatan Berastagi.
Lahan dengan kemiringan lereng 2545 (Curam dengan skor 80 ada di beberapa daerah yaitu Kecamatan Snmbah Hilir, Biru Biru, Sibolangit, tiga panah, sinembah hulu.

\section{Curah Hujan}

Curah hujan merupakan jumlah air yang jatuh di permukaan tanah datar selama periode tertentu. Intensitas curah hujan adalah ketinggian curah hujan yang terjadi pada suatu kurun waktu dimana air tersebut terkonsentrasi. Curah hujan yang turun akan mempengaruhi kondisi air tanah, tanah yang kandungan air tanahnya meningkat maka akan meningkatkan massanya dan semakin rendah tingkat kepadatan dan kekompakannya yang akan menambah kerentanan tanah untuk tererosi.

Tabel 8. Curah Hujan DAS Percut

\begin{tabular}{cccccc}
\hline No & $\begin{array}{c}\text { Curah hujan } \\
(\mathrm{mm} / \text { tahun) }\end{array}$ & Klasifikasi & Skor & Luas (Ha) & Presentase (\%) \\
\hline 1 & $<1000$ & Sangat kering & 10 & - & 0 \\
\hline 2 & $1001-1500$ & Kering & 20 & $24.759,57$ & $60 \%$ \\
\hline 3 & $2001-2500$ & Sedang & 30 & $17.998,62$ & $40 \%$ \\
\hline 4 & $2501-4000$ & Basah & 40 & - & - \\
\hline 5 & $>4000$ & Sangat basah & 50 & - & - \\
\hline & Total & & & $42.758,19$ & $100 \%$ \\
\hline
\end{tabular}

Sumber: Pengolahan Data Spasial, 2017

Daerah dengan curah hujan 1001-2000 $\mathrm{mm} /$ tahun di dua lokasi, yaitu Kecamatan Belawan, Labuhan,Deli, Percut Sei Tuandengan luas mencapai24.759,57 $\mathrm{Ha}$ dan Kecamatan Medan Deli, Medan Timur, Perjuangan,Medan Kota, Medan Amplas, Medan Denai, Medan Area Tembungsinembah Hilir dengan luas, Kecamatan Sibolangit, Barus Jahe, Tiga
Panah, Sinembah Hulu dengan luas 17.998,62 Ha.

Daerah dengan curah hujan 2001-2 $500 \mathrm{~mm} /$ tahun yaitu terdapat di daerah kecamatan Patumbak,Sibolangit, Medan Denai, Tembung, Kota, Area, Kecamatan Biru Biru dan Kecamatan Sinembah Hilir. Sebaran spasial jenis tanah, kemiringan lereng, dan curah hujan DAS Percut dapat dilihat pada Gambar 2 berikut. 

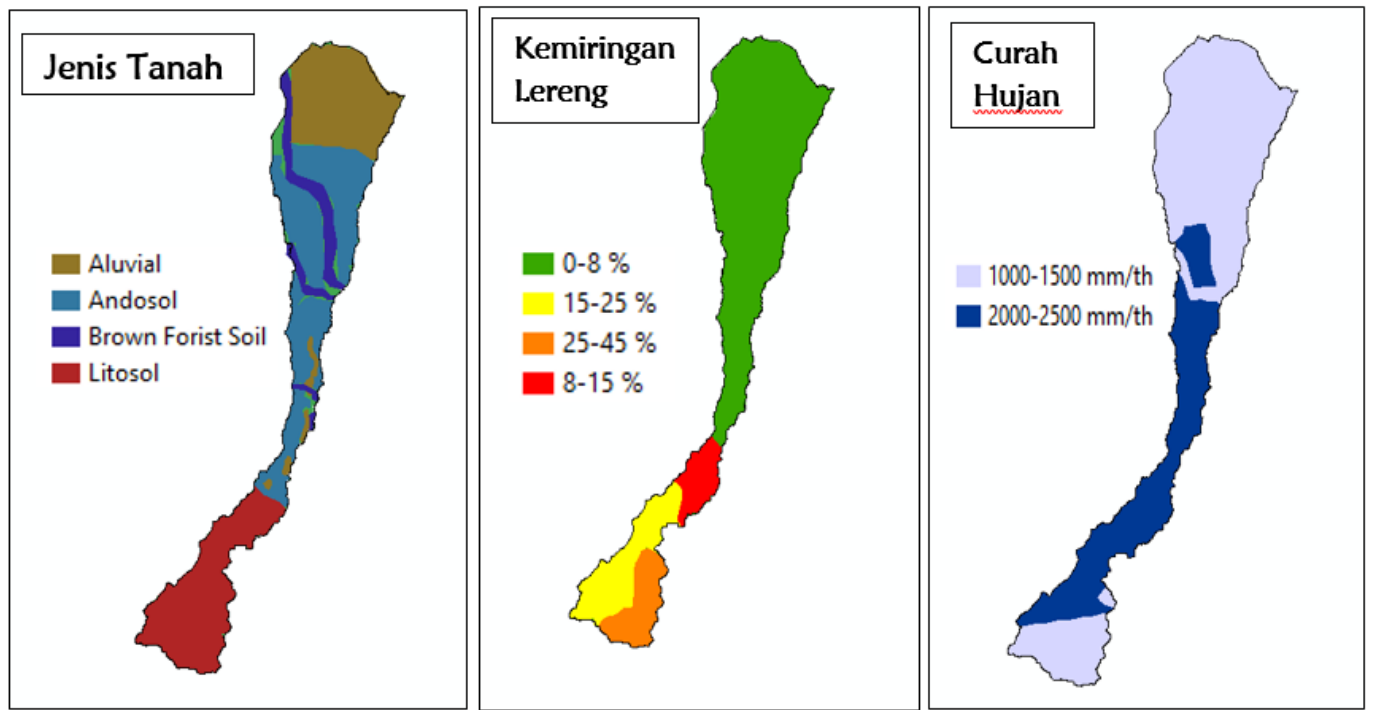

Gambar 2. Jenis Tanah, Kemiringan Lereng, dan Curah Hujan DAS Percut

\section{Arahan Penggunaan Lahan}

Dari hasil overlay peta kemiringan lereng, peta jenis tanah, dan peta curah hujan dengan menggunakan metode skoring dan penentuan arahan penggunaan lahan berpedoman pada SK Menteri Pertanian No. 837 / Kpts / Um / 8/1981, maka di DAS Percut (Tiga ) arahan pemanfaatan lahan yang tersebar di beberapa lokasi, yaitu arahan fungsi lindung, arahan budidaya tanaman semusim dan pemukiman. Lebih jelas mengenai luas arahan pengunaan lahan dapat dilihat pada Tabel 9 dan Gambar 3 berikut.

Tabel 9. Arahan Penggunaan Lahan DAS Percut

\begin{tabular}{|c|c|c|c|}
\hline No. & Arahan penggunaan lahan & Luas $(\mathrm{Ha})$ & Presentase (\%) \\
\hline 1 & Lindung & $4.258,19$ & $9,9 \%$ \\
\hline 2 & Penyangga & 9.250 & $21,7 \%$ \\
\hline 3 & Budidaya (Tahunan, Semusim, dan Permukiman) & 29.250 & $68,4 \%$ \\
\hline & Total & 42.758 .19 & 100 \\
\hline
\end{tabular}

Sumber: Analisis data, 2017

Dari Tabel 9 diatas dapat diketahui arahan penggunaan lahan fungsi lindung dengan total skor z 175 atau syarat ketinggian lebih dari 2000 mdpl. Luas arahan penggunaan lahan fungsi lindung mencapai $4.258,19 \mathrm{Ha}$ atau $9,9 \%$ dari luas keseluruhan daerah penelitian. Kawasan lindung ini tersebar di beberapa Kecamatan yaitu Kecamatan Barus Jahe, Sinembah Tg Hulu, Kecamatan Sibolangit, Kecamatan Biru Biru dan Kecamatan Sinembah Tg Hilir.

Arahan penggunaan lahan fungsi penyangga dengan total skor 125-174. Luas arahan penggunaan lahan fungsi penyangga sekitar9.250 atau $21,7 \%$ dari luas keseluruhan daerah penelitian. Kawasan Penyangga ini tersebar di beberapa Kecamatan Sibolangit, Kecamatan Biru Biru dan Kecamatan Tiga Panah, Kecamatan Sinembah Tg Hilir.

Arahan penggunaan lahan fungsi budidaya tanaman musim dan permukiman dengan total skor $<125$ dan Arahan memanfaatkan lahan ini yang terluas, mencapai 29.250 atau $68,4 \%$ dari luas keseluruhan DAS Percut. Kawasan Budidaya Tanaman Semusim dan Pemukiman ini tersebar di Kecamatan Medan Belawan, Kecamatan Medan Labuhan, Kecamatan Percut Sei Tuan, Kecamatan Medan Deli, Kecamatan Labuhan Deli, Kecamatan Medan Tembung, Kecamatan Medan Kota, Kecamatan Medan Area, Kecamatan Medan Amplas, Kecamatan Medan Tembung, Kecamatan Medan Denai, Kecamatan Patumbak, Kecamatan Sinembah Tg Muda Hilir, Kecamatan Biru Biru. 

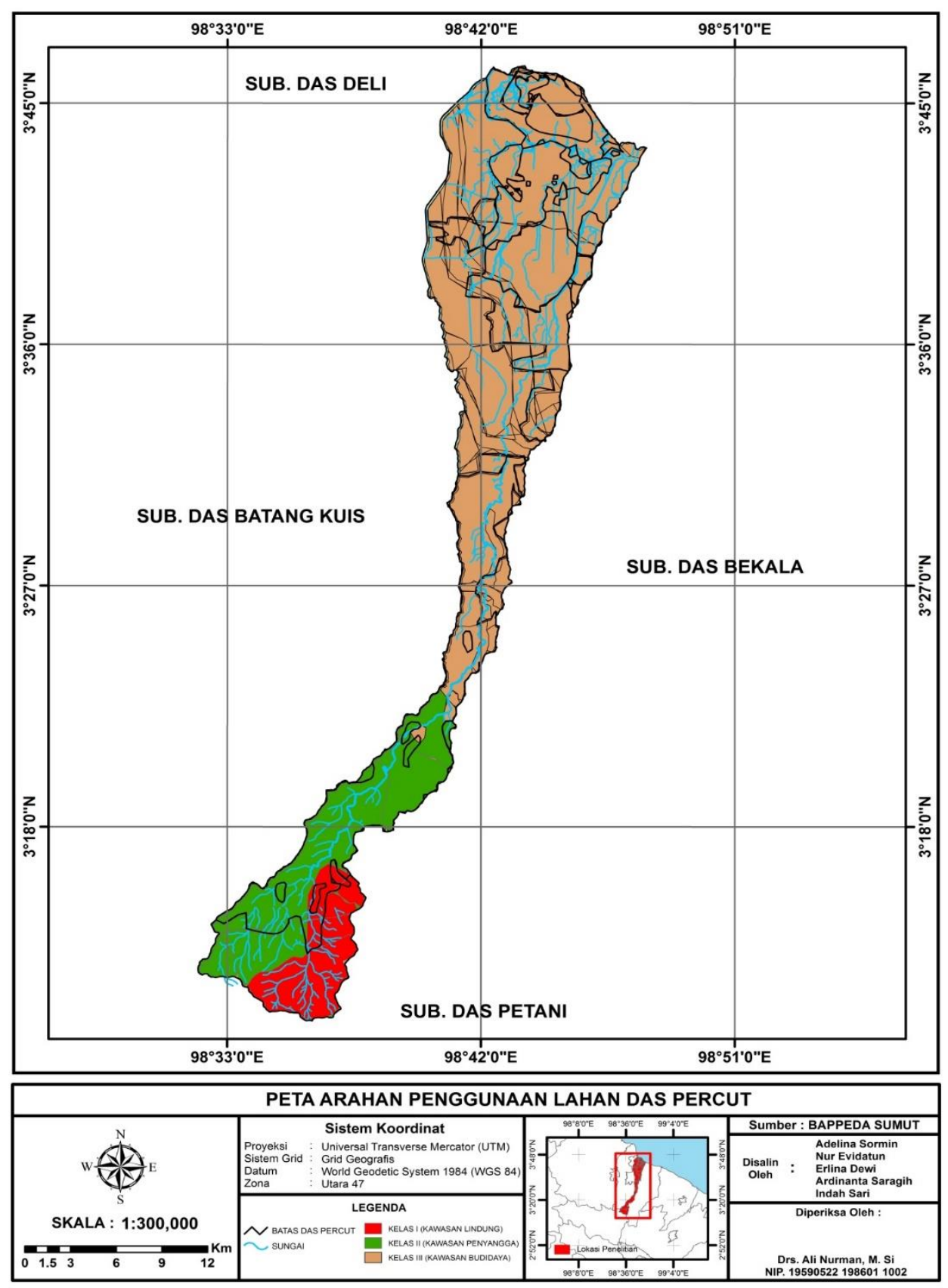

Gambar 3. Arahan Penggunaan Lahan DAS Percut

Arahan penggunaan lahan merupakan upaya penataan suatu wilayah menjadi suatu kawasan kawasan dengan fungsi berbeda beda sesuai dengan kemampuannya. Berdasarkan data sekunder pada 3 parameter yang ditetapkan oleh SK Mentan Nomor 837/Kpts/Um/11/80 yaitu jenis tanah, curah hujan dan kemiringan lereng.

Jenis tanah yang paling dominan adalah jenis tanah Andosol dengan tingkat kerentanan peka terhadap erosi dan skor 45 memiliki luas mencapai $15.641,20 \mathrm{Ha}$ atau
$36,58 \%$ dari luas total wilayah penelitian. Jenis tanah ini tersebar di beberapa kecamatan precut sei tuan, Medan Tembung, Medan Perjuangan, Medan Timur, Medan deli, Medan Amplas, Patumbak, tanjung Morawa, Kecamatan Biru Biru. Jenis tanah Aluvial dengan tingkat atas Tidak Peka terhadap erosi dan skor 15 memiliki luas mencapai $11.203,96 \mathrm{Ha}$ atau $26,20 \%$ dari luas total wilayah penelitian. Jenis tanah ini tersebar di beberapa Kecamatan Medan Labuhan, Belawan, 
Patumbak, Sinembah Tanjung Muda Hilir, Biru Biru.

Jenis tanah Brown Forist Soil dengan tingkat Kurang Peka terhadap erosi dan skor 45 memiliki luas sekitar 3.730,52 $\mathrm{Ha}$ atau $8,72 \%$ dari luas. Jenis tanah ini tersebar di beberapa Kecamatan Labuhan, Belawan, Deli, Medan Area, Medan Kota, Patumbak, Sinembah Tanjung Muda Hilir.

Jenis Tanah Latosol dengan tingkat sangat pekaterhadap erosi dengan skor 75 memiliki luas sekitar $11.659,34 \mathrm{Ha}$ atau 28,5 $\%$ luas keseluruhan daerah penelitian. Jenis tanah latosol menyebar di beberapa kecamatanBiru Biru, Sibolangit, Tiga Panah, dan Barus Jahe.

Dari hasil analisis Peta Kemiringan Lereng maka didapat daerah dengan kelerengan 0-8 (datar) dengan skor 20 ada di seluruh wilayah daerah yaitu Kecamatan Patumbak, Tanjung Morawa, Kecamatan Sinembah Tanjung Hilir, Medan Labuhan, Labuhan Deli, Kecamatan Percut Sei Tuan, Kecamatan Medan Denai, Kecamatan Medan Timur, Kecamatan Medan Amplas dan Belawan. Lahan dengan kemiringan lereng $8-15 \%$ Landai dengan skor 40 ada juga di seluruh daerah yaituKecamatan Sinembah Tg Muda Hilir ,Kec Biru Biru. Lahan dengan kemiringan lereng 15-25 Agak Curam dengan skor 60 ada juga di seluruh daerah penelitian yaitu Kecamatan Kecamatan Sibolangit, Kecamatan Biru Biru,Kecamatan Tiga Panah, Kecamatan Berastagi. Lahan dengan kemiringan lereng 2545 (Curam dengan skor 80 ada di beberapa daerah yaitu Kecamatan Snmbah Hilir, Biru Biru,Sibolangit, Snmbh hulu, tiga panah, sinembah hulu.

Daerah dengan curah hujan 1001-2000 $\mathrm{mm} /$ tahun di dua lokasi, yaitu Kecamatan Belawan, Labuhan,Deli, Percut Sei Tuandengan luas mencapai 24.759,57 $\mathrm{Ha}$ dan Kecamatan Medan Deli, Medan Timur, Perjuangan,Medan Kota, Medan Amplas, Medan Denai, Medan Area TembungSinembah Hilir dengan luas, Kecamatan Sibolangit, Barus Jahe, Tiga Panah, Sinembah Hulu dengan luas 17.998,62 Ha. Daerah dengan curah hujan 2001-2 500mm / tahun yaitu terdapat di daerah kecamatan Patumbak,Sibolangit, Medan Denai, Tembung, Kota, Area, Kecamatan Biru Biru dan Kecamatan Sinembah Hilir.

Dari data ketiga parameter tersebut dihasilkan 3 Kawasan arahan penggunaan lahan di DAS Percut yaitu arahan kawasan
Lindung dengan kategori Kelas I dengan luas 4.258,19 $\mathrm{Ha}$ atau 9,9\% dari luas keseluruhan daerah penelitian. Kawasan lindung ini tersebar di beberapa Kecamatan yaitu Kecamatan Barus Jahe, Sinembah Tg Hulu, Kecamatan Sibolangit, Kecamatan Biru Biru dan Kecamatan Sinembah Tg Hilir. Kawasan ini berada pada daerah hulu DAS Percut.

Arahan penggunaan lahan fungsi penyangga dengan total skor 125-174. Pada Kepres No. 32 tahun 1990 tentang pegelolaan Kawasan Lindung dalam kawasan bencana kawasan lindung adalah kawasan yang ditetapkan dengan fungsi utama melindungi kelestarian lingkungan hidup yang merupakan sumber alam, sumber daya buatan dan nilai sejarah bangsa untuk kepentingan pembangunan berkelanjutan . Adapun yang termasuk kawasan lindung adalah :

- Kawasan yang menyediakan kawasan kawasan bawahannya (kawasan hutan lindung, kawasan bergambut, dan kawasan resapan air).

- Kawasan resapan udara (sempadan pantai, sempadan sungai, kawasan sekitar danau, dan kawasan sekitar mata air).

- Kawasan suaka alam dan cagar budaya (kawasan suaka alam, kawasan suaka alam laut dan lain-lain, kawasan pantai berhutan bakau, taman nasional, taman hutan raya dan taman wisata alam, dan $\mathrm{k}$ cagar budaya dan ilmu pengetahuan).

- Kawasan rawan bencana alam.

Menurut Balai Rehabilitasi Lahan dan Konservasi Tanah (1995), Kawasan fungsi penyangga adalah suatu wilayah yang dapat berfungsi lindung dan berfungsi budidaya, letaknya antara kawasan fungsi lindung dan kawasan fungsi budidaya seperti hutan produksi terbatas, perkebunan (tanaman keras), kebun campur dan lain yang sejenis. Satuan lahan dengan jumlah skor ketiga karakteristik fisiknya antara 125-174 serta memenuhi kriteria umum sebagai berikut: 1) Keadaan fisik satuan lahan untuk dilakukan budidaya; 2) Lokasinya secara ekonomis sudah dikembangkan sebagai kawasan penyangga.

Luas arahan penggunaan lahan fungsi penyangga sekitar 9.250 atau $21,7 \%$ dari luas keseluruhan daerah penelitian. Kawasan Penyangga ini tersebar di beberapa Kecamatan Sibolangit, Kecamatan Biru Biru dan Kecamatan Tiga Panah, 
Kecamatan Sinembah Tg Hilir. Arahan penggunaan lahan fungsi budidaya tanaman musim dan permukiman dengan total skor $<125$ dan Arahan memanfaatkan lahan ini yang terluas, mencapai 29.250 atau $68,4 \%$ dari luas keseluruhan DAS Percut.

Kawasan fungsi budidaya tanaman tahunan adalah kawasan budidaya yang diusahakan dengan tanaman tahunan seperti Hutan Produksi Tetap, Hutan Tanaman Industri, Hutan Rakyat, Perkebunan (tanaman keras), dan tanamn buah-buahan. Satuan lahan dengan jumlah skor tiga karakteristik fisiknya lebih kecil 124 serta sesuai untuk dikembangkan usaha tani tanaman tahunan. Selain itu harus memenuhi kriteria umum untuk kawasan penyangga.

Kawasan fungsi budidaya tanaman semusim dan permukiman adalah kawasan yang memiliki fungsi budidaya dan diusahakan dengan tanaman semusim pada tanaman pangan atau untuk pemukiman. Untuk menjaga kelestarian kawasan fungsi budidaya tanaman semusim, pemilihan jenis komoditi harus kesesuaian fisik terhadap komoditi yang akan dikembangkan. Satuan lahan dengan kriteria seperti dalam penetapan kawasan budidaya tanaman tahunan serta terletak di tanah milik, tanah adat dan tanah negara yang seharusnya dikembangkan usaha tani tanaman semusim.

Kawasan Budidaya Tanaman Semusim dan Pemukiman ini tersebar di Kecamatan Medan Belawan, Kecamatan Medan Labuhan, Kecamatan Percut Sei Tuan, Kecamatan Medan Deli, Kecamatan Labuhan Deli, Kecamatan Medan Tembung, Kecamatan Medan Kota, KecamatanMedan Area, Kecamatan Medan Amplas, Kecamatan Medan Tembung, Kecamatan Medan Denai, Kecamatan Patumbak, Kecamatan Sinembah Tg Muda Hilir, Kecamatan Biru Biru.

\section{KESIMPULAN DAN SARAN}

Berdasarkan hasil penelitian yang diperoleh maka dapat disimpulkan bahwa Arahan Penggunaan Lahan di DAS Percut terdiri dari 3 kawasan, yaitu Kawasan Lindung dengan luas 4.258,19 $\mathrm{Ha}$ atau 9,9\% dari keseluruhan daerah penelitian. Kawasan penyangga yaitu dengan luas 9.250 $\mathrm{Ha}$ atau (21,7\%) dan Kawasan Budidaya tanaman semusim dan permukiman yaitu dengan luas $29.250 \mathrm{Ha}$ atau $(68,4 \%)$.
Berdasarkan kesimpulan yang diperoleh maka dapat disarankan beberapa hak sebagai berikut:

1. Masyarakat yang berada di daerah hulu dan hilir das percut untuk lebih memperhatikan kondisi berdasarkan karakteristiknya dalam upaya pembangunan berkelanjutan.

2. Peran serta pemerintah dalam menghimbau masyarakat dalam upaya pemanfaatan ruang yang sesuai dengan peruntukannya.

\section{DAFTAR PUSTAKA}

Adnyana, I. W. S., \& As-syakur, A. R. (2012). Aplikasi Sistem Informasi Geografi Berbasis Data Raster Untuk Pengkelasan Kemampuan Lahan Di Provinsi Bali Dengan Metode Nilai Piksel Pembeda (Application of Geographic Information System (Gis) Based Raster Data to Classify Land Capability in Bali). Jurnal Manusia dan Lingkungan, 19(1), 21-29.

Arsyad, S. (2009). Konservasi Tanah \& Air. Bogor: IPB Press.

Asdak, C. (2004). Hidrologi dan Pengelolaan Daerah Aliran Sungai. Yogyakarta. https://doi.org/2002

Balai Besar Litbang Sumberdaya Lahan Pertanian (BBSDLP). 2009. Identifikasi dan Karakterisasi Lahan Rawan Longsor dan Rawan Erosi di Dataran Tinggi untuk Mendukung Keberlanjutan Pengelolaan Sumberdaya Lahan Pertanian. BBSDLP, Bogor.

Balai Rehabilitasi Lahan dan Konservasi Tanah (BRLKT), 1995. Petunjuk Pelaksanaan Penyusunan RTL-RLKT. Jakarta. Departemen Kehutanan RI.

Damanik, M. R. S., \& Restu, R. (2012). Pemetaan Tingkat Risiko Banjir dan Longsor Sumatera Utara Berbasis Sistem Informasi Geografis. JURNAL GEOGRAFI, 4(1), 29-42.

Fitrianti, F., Sugiyanta, I. G., \& Miswar, D. (2013). PEMETAAN ARAHAN FUNGSI PEMANFAATAN LAHAN UNTUK KAWASAN FUNGSI LINDUNG. JPG (Jurnal Penelitian Geografi), 1(5).

Listyawati, H. (2010). Kegagalan Pengendalian Alih Fungsi Tanah 
dalam Perspektif Penatagunaan Tanah di Indonesia. Mimbar HukumFakultas Hukum Universitas Gadjah Mada, 22(1), 37-57.

Keputusan Presiden Nomor 32 Tahun 1990 tentang parameter kemiringan lereng, dan jenis tanah.

Nursa'ban, M. (2006). Pengendalian Erosi Tanah Sebagai Upaya Melestarikan Fungsi Lingkungan. Geomedia, Volume 4, Nomor 2, November 2006. https://doi.org/10.1186/14712334-13-196

Pahlawan, J. R., \& Worosuprojo, S. (2013). Kajian Pengelolaan Lahan Subdas Secang Kulonprogo YOGYAKARTA. Jurnal Bumi Indonesia, 2(2).

Pawitan, H. (2004). Perubahan penggunaan lahan dan pengaruhnya terhadap hidrologi Daerah Aliran Sungai. Laboratorium Hidrometeorologi FMIPA IPB, Bogor.

Putra, C. D., Mardiatno, D. (2012). Kemampuan lahan untuk arahan kawasan budidaya dan non budidaya sub daerah aliran sungai petir di Daerah Istimewa Yogyakarta. Jurnal bumi indonesia, 1(2).

Rahmad, R., Nurman, A., \& Wirda, M. A. (2017). Integrasi Model SWAT dan SIG dalam Upaya Menekan Laju Erosi DAS Deli, Sumatera Utara. Majalah Geografi Indonesia, 31(1), 46-55.
Retrieved from https://journal.ugm.ac.id/mgi/article/ viewFile/24232/15947

Rahmad, R., Suib, S., \& Nurman, A. (2018). Aplikasi SIC untuk Pemetaan Tingkat Ancaman Longsor di Kecamatan Sibolangit, Kabupaten Deli Serdang, Sumatera Utara. Majalah Geografi Indonesia, 32(1), 1-13. https://doi.org/https://doi.org/10.221 46/mgi.31882

Sheng. T. C. 1968. Concepts of Watershed Management. Lecture Notes for Forest Training Course in Watershed Management and Soil Conservation. UNDP/FAO. Jamaica.

Sinukaban, N. (2001). Impact of Upland Agriculture and Conservation Project ( UACP ) on Sustainable Agriculture Development in Serang Watershed, Indonesia. In Sustaining the Global Farm.

Surat Keputusan Menteri Pertanian Nomor 837/KptsUm /11/1980 Tentang Kriteria dan Tata Cara Penetapan Hutan Lindung.

Surat Keputusan Menteri Pertaniaan Nomor 683/Kpts/Um/8/1981 tentang Kriteria dan Tata Cara Penetapan Hutan Produksi.

Undang-undang RI No. 7 Tahun 2004. Tentang Sumberdaya Air. 